the selection of the vectors that are used in two-hybrid strategies. MG7 $\alpha$ contains a deletion of the endA gene, compared to the point mutation in $\mathrm{DH} 5 \alpha$, which still allows for a residual level of endonuclease activity $(14,15)$. The end $A$ knock-out removes any residual end $A$ activity and thus allows MG7 $\alpha$ to produce higher quality plasmid DNA preparations than strains carrying end $A$ point mutations. In addition to its use in the yeast two-hybrid system, the qualities that it inherits from its parent strain, $\mathrm{DH} 5 \alpha$, and the end $A$ deletion we have introduced, make it a good all-purpose laboratory strain. This strain will be made available through ATCC (Reference no. MBA-78; Manassas, VA, USA).

\section{REFERENCES}

1.Bolivar, F., R.L. Rodriguez, P.J. Greene, M.C. Betlach, H.L. Heynecker, H.W. Boyer, J.H. Crosa, and S. Falkow. 1977. Construction and characterization of new cloning vehicles. II. A multipurpose cloning system. Gene 2:95-113.

2.Fields, S. and O. Song. 1989. A novel genetic system to detect protein-protein interactions. Nature 340:245-246.

3.Ratzkin, B. and J. Carbon. 1977. Functional expression of cloned yeast DNA in EScherichia coli. Proc. Natl. Acad. Sci. USA 74:487-491.

4.Struhl, K., D.T. Stinchcomb, S. Scherer, and R.W. Davis. 1979. High-frequency transformation of yeast: autonomous replication of hybrid DNA molecules. Proc. Natl. Acad. Sci. USA 76:1035-1039.

5.Datsenko, K.A. and B.L. Wanner. 2000. One-step inactivation of chromosomal genes in Escherichia coli K-12 using PCR products. Proc. Natl. Acad. Sci. USA 97:6640-6645.

6.Sambrook, J., E.F. Fritsch, and T. Maniatis. 1989. Molecular Cloning: A Laboratory Manual. CSH Laboratory Press, Cold Spring Harbor, NY.

7.Birnboim, H.C. and J. Doly. 1979. A rapid alkaline extraction procedure for screening recombinant plasmid DNA. Nucleic Acids Res. 7:1513-1523.

8.Girvitz, S.C., S. Bacchetti, A.J. Rainbow, and F.L. Graham. 1980. A rapid and efficient procedure for the purification of DNA from agarose gels. Anal. Biochem. 106:492-496.

9.Gietz, R.D. and A. Sugino. 1988. New yeastEscherichia coli shuttle vectors constructed with in vitro mutagenized yeast genes lacking six-base pair restriction sites. Gene 74:527534.

10.Sikorski, R.S. and P. Hieter. 1989. A system of shuttle vectors and yeast host strains designed for efficient manipulation of DNA in Saccharomyces cerevisiae. Genetics 122:1927.

11.Dower, W.J., J.F. Miller, and C.W. Ragsdale. 1988. High efficiency transformation of $E$. coli by high voltage electroporation. Nucleic Acids Res. 16:6127-6145.

12.Blattner, F.R., G. Plunkett, C.A. Bloch, N.T. Perna, V. Burland, M. Riley, J. ColladoVides, J.D. Glasner, et al. 1997. The complete genome sequence of Escherichia coli K-12. Science 277:1453-1474.

13.Murphy, K.C. 1998. Use of bacteriophage lambda recombination functions to promote gene replacement in Escherichia coli. J. Bacteriol. 180:2063-2071.

14.Cherepanov, P.P. and W. Wackernagel. 1995. Gene disruption in Escherichia coli: $\mathrm{TcR}$ and $\mathrm{KmR}$ cassettes with the option of Flpcatalyzed excision of the antibiotic-resistance determinant. Gene 158:9-14.

15.Durwald, H. and H. Hoffmann-Berling. 1968. Endonuclease I-deficient and ribonuclease I-deficient Escherichia coli mutants. J. Mol. Biol. 34:331-346.

16.Woodcock, D.M., P.J. Crowther, J. Doherty,
S. Jefferson, E. DeCruz, M. Noyer-Weidner, S.S. Smith, M.Z. Michael, et al. 1989. Quantitative evaluation of Escherichia coli host strains for tolerance to cytosine methylation in plasmid and phage recombinants. Nucleic Acids Res. 17:3469-3478.

Received 10 March 2003; accepted 16 May 2003.

Address correspondence to Daniel Gietz, Department of Biochemistry and Medical Genetics, University of Manitoba, Room P306, Pathology Building, 770 Bannatyne Avenue, Winnipeg, MB, Canada MR3E oW3.e-mail: gietz@cc.umanitoba.ca

\title{
Rapid isolation of Arabidopsis thaliana developing embryos
}

\author{
Sharyn E. Perry and Huai Wang \\ University of Kentucky, Lexington, $K Y, U S A$
}

BioTechniques 35:278-282 (August 2003)

Arabidopsis thaliana is a model plant for which many genetic and molecular tools are available. Another advantage of $A$. thaliana is its small size, allowing many plants to be grown in limited space. However, the diminutive size makes some experiments difficult. In particular, it is laborious to obtain enough isolated embryos for molecular or biochemical studies. Experiments involving developing embryos are further complicated because tissues containing $A$. thaliana embryos, such as siliques and seeds, can be difficult to work with because of secondary metabolites and polysaccharides. For example, we have found that RNA cannot be obtained from siliques or seeds using commercially available RNA isolation kits, such as RNeasy ${ }^{\circledR}$ (Qiagen, Valencia, CA, USA) or TRIzOL ${ }^{\circledR}$ reagent (Invitrogen, Carlsbad, CA, USA), methods that are widely used because they are fast and easy. Protocols to obtain RNA from these tissues are considerably more involved $(1,2)$.

Here we describe a simple method, based on density gradient centrifugation, to isolate relatively large quantities of $A$. thaliana embryos. Our method is faster and requires less handling of individual seeds and embryos than does manual dissection. Approximately $100 \mathrm{mg}$ torpedo to bent cotyledon stage embryos can be isolated in an afternoon. It is possible to isolate even younger embryos, as early as late heart stage. The embryos are suitable for a variety of experiments, including RNA isolation and protein extraction and analysis.

Developing siliques were opened and seeds removed into a few drops of $\mathrm{MC}$ buffer for protein work (3) (MC buffer is $10 \mathrm{mM}$ potassium phosphate, $\mathrm{pH}$ 7.0, $50 \mathrm{mM} \mathrm{NaCl}, 0.1 \mathrm{M}$ sucrose), or RNAlater ${ }^{\mathrm{TM}}$ (Qiagen) for RNA isolation, on a glass microscope slide. 


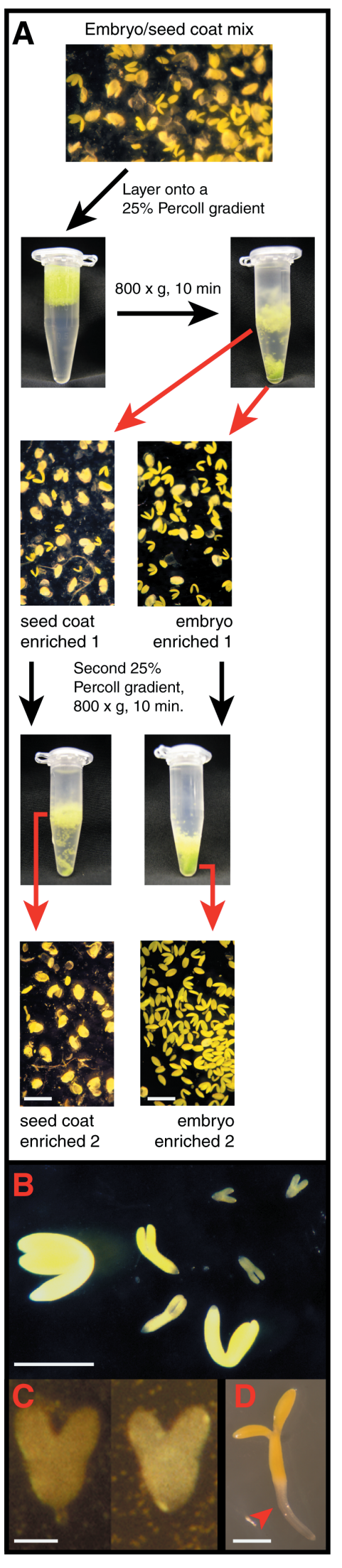

280 BioTechniques

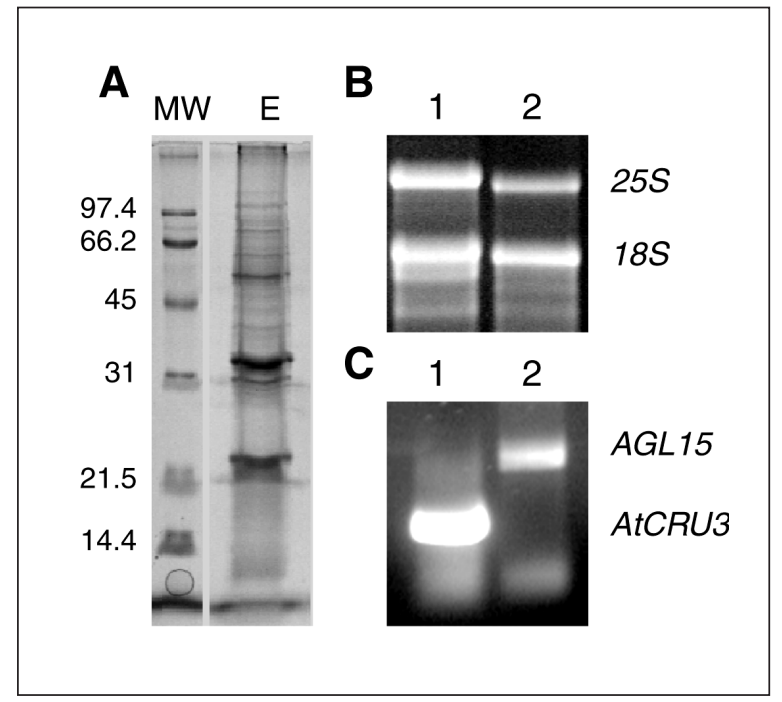

Figure 2. Protein and nucleic acid extractions from isolated embryos. (A) Proteins were extracted from isolated embryos, separated by sodium dodecyl sulfate polyacrylamide gel electrophoresis (SDS-PAGE), and stained with Coomassie Brilliant Blue R-250. Embryo extract $(\mathrm{E} ; 50 \mu \mathrm{g})$ was loaded on the gel. (B) RNA was isolated from whole plants (lane 1) and from isolated embryos (lane 2) using TRIzol reagent. Total RNA $(5 \mu \mathrm{g})$ was analyzed by agarose gel electrophoresis. Images were captured using a ChemiImager ${ }^{\mathrm{TM}}$ (Alpha Innotech, San Leandro, CA, USA). (C) Oligonucleotide primers to amplify one of the $12 S$ cruciferins (lane 1) or $A G L 15$ (lane 2) were used to perform RT-PCR analysis of RNA extracted from isolated embryos. The PCR products were visualized on a $1.2 \%$ agarose gel and captured as described above.

After collecting seeds from 10-20 siliques, a second glass microscope slide was placed on top of the seeds and gently pressed downward with slight rotation, causing the seed coats to rupture and the embryos to emerge from the seed coats. Progress may be monitored under a dissecting microscope. The embryo/seed coat mixture was collected on ice in buffer for protein work, or at room temperature in RNAlater for RNA isolation. Seeds from approximately 200 siliques can be collected within $2-2.5 \mathrm{~h}$. This was enough material to obtain nearly $100 \mathrm{mg}$ isolated torpedo to bent cotyledon stage embryos.

Once collection was complete, the embryo/seed coat mixture was concen-

Figure 1. Embryo/seed coat fractionation protocol. (A) Flowchart showing the procedure to separate seed coats from developing embryos. Bars $=1 \mathrm{~mm}$. (B and C) Examples of embryos obtained in the embryo enriched fraction after the second Percoll cushion. $\mathrm{Bar}=0.5 \mathrm{~mm}$ in panel $\mathrm{B}$ and $50 \mu \mathrm{m}$ in panel C. (D) Embryos isolated over Percoll/MC buffer are viable. The root elongated after 3 days in culture (arrowhead). Bar $=0.5 \mathrm{~mm}$. trated in a microcentrifuge with a brief spin (10-s pulse, top speed). The mixture was resuspended in buffer to isolate embryos for protein extraction. For seeds from 150-200 siliques, approximately $2 \mathrm{~mL}$ MC buffer gave a thick suspension. The suspension was layered onto a $25 \%$ Percoll $^{\circledR}$ (Sigma, St. Louis, MO, USA) cushion in MC buffer. Approximately 0.6 $\mathrm{mL}$ suspension was layered onto a 1-mL Percoll cushion in an Eppendorf ${ }^{\circledR}$ tube. Figure 1A outlines the protocol and shows the embryo/seed coat mixture and the appearance of the Percoll cushions before and after centrifugation at $800 \times g$ for 10 min. As shown in Figure $1 \mathrm{~A}$, the pellet is enriched for embryos (embryo enriched 1), while the material that remains near the top of the Percoll cushion is enriched for seed coats (seed coat enriched 1). Significant cross-contamination exists, and cleaner fractions can be obtained by reisolation of embryos or seed coats on second Percoll cushions. To do this, fractions were collected from the first gradient and concentrated by a brief centrifugation in a microcentrifuge. The seed coat- and embryo-enriched pellets were resuspended in $1 \mathrm{~mL}$ MC buffer and layered onto 25\% Percoll cushions as described above. After centrifugation at $800 \times g$ for $10 \mathrm{~min}$, the seed coat cushion had a small pellet at the bottom of the tube that was enriched for embryos. The portion of the tissue that remained near the top of the cushion was nearly entirely seed coat (seed coat enriched 2; Figure 1A). The embryo cushion had a compact pellet at the bottom of the tube and looser material above. The supernatant and loose material (mixture of seed coat and embryo) were removed, and the pellet was resuspended in buffer to wash. The pellet is nearly entirely embryos (embryo enriched 2; Figure 1A). Percoll may be removed 
from the seed coat and embryo fraction by resuspension in buffer and brief centrifugation. Buffer may be removed using a drawn-out Pasteur pipet, and the fractions may be frozen in liquid nitrogen. Even relatively young embryos can be isolated by this method. As shown in Figure 1, B and C, respectively, young torpedo (6-7 days after flowering under growth conditions of $20^{\circ} / 18^{\circ} \mathrm{C}, 16-\mathrm{h}$ light/8-h dark regime) and heart stage (4-5 days after flowering) embryos were recovered in the embryo-enriched pellet after the second Percoll gradient. Embryos isolated using Percoll in MC buffer were viable after isolation. As shown in Figure 1D, after 3 days in culture on germination media (MS salts and vitamins as in Reference 4, supplemented with $10 \mathrm{~g} / \mathrm{L}$ sucrose, $0.5 \mathrm{~g} / \mathrm{L}$ MES, and $7 \mathrm{~g} / \mathrm{L}$ agar, $\mathrm{pH}$ 5.6-5.7), the root elongated. Fractions were observed under a Zeiss ${ }^{\circledR}$ Stemi 2000-C stereomicroscope equipped with a $35-\mathrm{mm}$ camera (Carl Zeiss, Thornwood, NY, USA). Slides were scanned using a Nikon ${ }^{\circledR}$ LS-2000 scanner (Nikon, Tokyo, Japan) and assembled using Adobe ${ }^{\circledR}$ Photoshop $^{\circledR} 5.0$ and Adobe Illustrator ${ }^{\circledR} 7.0$.

The same procedure was followed to collect embryos for RNA isolation, except that collection was at room temperature in RNAlater, the Percoll gradient was prepared with diethylpyrocarbonate (DEPC)-treated water instead of $\mathrm{MC}$ buffer, and the RNAlater was removed from the embryos by washing with DEPC-treated water before layering onto the Percoll cushion. Embryos were suspended in DEPC-treated water and applied to the Percoll cushion. All centrifugations were performed at $4^{\circ} \mathrm{C}$. The isolated embryos were washed at least twice with DEPC-treated water to remove Percoll before flash freezing in liquid nitrogen. Thirty minutes of collection and approximately another 30 min to process the two sequential Percoll gradients and wash the embryos yielded 10-20 mg embryos.

Embryos isolated through Percoll cushions were suitable as material for nucleic acid and protein extraction. Figure 2A shows total protein extracted from isolated embryos analyzed on a $12.5 \%$ sodium dodecyl sulfate polyacrylamide gel electrophoresis (SDSPAGE) gel and stained with Coomassie $^{\circledR}$ Brilliant Blue R-250 following standard procedures. Separated proteins could be transferred to membrane and probed with antisera by standard protocols (data not shown). In addition, intact RNA may be obtained using the TRIzoL method following the manufacturer's directions. For example, in one experiment, $16 \mathrm{mg}$ isolated embryos extracted using $1 \mathrm{~mL}$ TRIzoL reagent, yielded $28 \mu \mathrm{g}$ good-quality RNA, as shown in Figure 2B. The ratio of the absorbance measured at $260 \mathrm{~nm}$ to that measured at $280 \mathrm{~nm}$ was 2.09 (measured in $10 \mathrm{mM}$ Tris- $\mathrm{HCl}, \mathrm{pH}$ 7.5), indicating a highly purified preparation of RNA. However, we were unable to obtain any RNA using TRIzOL reagent and isolated seed coats or intact developing seeds (data not shown). The RNA obtained from the embryos is suitable for RT-PCR, as shown in Figure $2 \mathrm{C}$. Reverse transcription was performed as previously described (5), using $2 \mu \mathrm{g}$ total RNA. PCR was next performed using oligonucleotide primers specific for one of the $A$. thaliana $12 \mathrm{~S}$ cruciferins (AtCRU3; Figure $2 \mathrm{C}$, lane 1) or for the embryo-expressed MADS-box AGL15 (Figure $2 \mathrm{C}$, lane 2) $(6,7)$. PCR was performed with an initial denaturation at $95^{\circ} \mathrm{C}$ for $3 \mathrm{~min}$, followed by 30 cycles of $95^{\circ} \mathrm{C}$ for $30 \mathrm{~s}, 58^{\circ} \mathrm{C}$ for $30 \mathrm{~s}, 72^{\circ} \mathrm{C}$ for $45 \mathrm{~s}$, followed by a final extension at $72^{\circ} \mathrm{C}$ for $7 \mathrm{~min}$. mRNA from the highly expressed $A t C R U 3$, as well as from the low level of expression of $A G L 15$, could be detected in isolated embryos (Figure 2C), as could the ubiquitously expressed $\beta$-2-tubulin (8) and elongation factor 1- $\alpha$ (9) (data not shown).

\section{ACKNOWLEDGMENTS}

We are grateful to Mr. Weining Tang for helpful comments on the manuscript. This work was supported by the National Science Foundation grant no. IBN-9984274 to S.E.P. and by The University of Kentucky. This paper (no. 0306-054) is published with the approval of the Director of the Kentucky Agricultural Experiment Station.

\section{REFERENCES}

1.Ruuska, S.A. and J.B. Ohlrogge. 2001. Protocol for small-scale RNA isolation and tran- scriptional profiling of developing Arabidopsis seeds. BioTechniques 31:752-758.

2.Wilkins, T.A. and L.B. Smart. 1996. Isolation of RNA from plant tissue, p. 21-41. In P.A. Krieg (Ed.), A Laboratory Guide to RNA: Isolation, Analysis, and Synthesis. Wiley-Liss, New York.

3.Ito, T., N. Takahashi, Y. Shimura, and K. Okada. 1997. A serine/threonine protein kinase gene isolated by an in vivo binding procedure using the Arabidopsis floral homeotic gene product, AGAMOUS. Plant Cell Physiol. 38:248-258.

4.Murashige, T. and F. Skoog. 1962. A revised medium for rapid growth and bioassays with tobacco tissue cultures. Physiol. Plant 15:473497.

5.Wang, H., W. Tang, C. Zhu, and S.E. Perry. 2002. A chromatin immunoprecipitation (ChIP) approach to isolate genes regulated by AGL15, a MADS domain protein that preferentially accumulates in embryos. Plant J. 32:831-843.

6.Heck, G.R., S.E. Perry, K.W. Nichols, and D.E. Fernandez. 1995. AGL15, a MADS-domain protein expressed in developing embryos. Plant Cell 7:1271-1282.

7.Rounsley, S.D., G.S. Ditta, and M.F. Yanofsky. 1995. Diverse roles for MADS-box genes in Arabidopsis development. Plant Cell 7:1259-1269.

8.Snustad, D.P., N.A. Haas, S.D. Kopczak, and C.D. Silflow. 1992. The small genome of Arabidopsis contains at least nine expressed $\beta$-tubulin genes. Plant Cell 4:549-556.

9.Axelos, M., C. Bardet, T. Liboz, A.L.V. Thai, C. Curie, and B. Lescure. 1989. The gene family encoding the Arabidopsis thaliana translation elongation factor EF-1 $\alpha$ : molecular cloning, characterization, and expression. Mol. Gen. Genet. 219:106-112.

Received 18 April 2003; accepted 16 May 2003.

Address correspondence to Sharyn E. Perry, University of Kentucky, Department of Agronomy, 352 Plant Science Building, 1405 Veterans Road, Lexington, KY $40546-$ 0312,USA.e-mail:sperr2@uky.edu 